\section{Balance of reciprocity and influence in family-school interactions in early childhood education: A socio-psychological perspective}

\author{
Ntim, Stephen \\ Catholic University of Ghana, Fiapre, Ghana (stephen.ntim@cug.edu.gh) \\ Opoku-Manu, Michael \\ Catholic University of Ghana, Fiapre, Ghana (sasfynba@gmail.com)
}

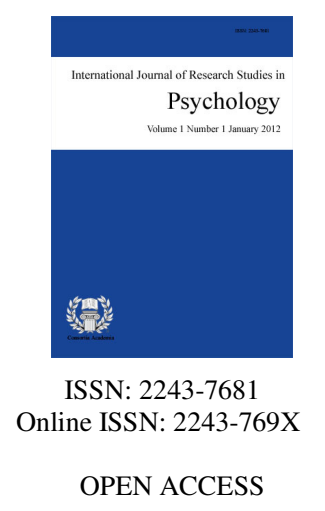

Accepted: 17 May 2019

\title{
Abstract
}

This study reports the differential roles of teachers and parents at the level of Early Childhood Education in Ghana. Using random stratified purposive sampling of one hundred and forty respondents, the following were the key findings: a) parents and teachers showed differences and similarities in their over-all assessment of the perception of their respective roles; $b$ ) professional judgment of teachers on parental involvement indicated that teachers at the Early Childhood Education level expected parents to be involved in the homes and in the schools, but with the appropriate level of parental involvement in the latter; c) whether or not parents felt obliged to be involved was critically shaped by their attitudes which in turn were influenced by their background, especially educational attainment. Significant differences were observed. While parental responses suggested unequal dependencies in all key domains among rural and less educated parents, it was less so with urban educated parents.

Keywords: early childhood education; parents; teachers; perception; roles 


\section{Balance of reciprocity and influence in family-school interactions in early childhood education: A socio-psychological perspective}

\section{Introduction}

Contemporary educational reforms across the globe have consistently emphasized the need to close the achievement gap of children from diverse sociocultural and socioeconomic backgrounds. The aim is to ensure that all children learn towards attaining high standards. Within the context of these efforts, family involvement is one of the critical issues for a good reason. Copious research findings suggest that to facilitate good learning outcomes, effective home-school partnership cannot be underestimated (Abdulkadir, Ali, \& Raqia, 2018; Lewis $\&$ Henderson, 1997). Stronger family-school interactions constitute effective ways of fostering these connections and relationships. The objective is to ensure that children learn with ease when parents and teachers address possible obstacles in their learning (Christenson \& Sheridan, 2001). Again, findings show that the quality of family-school interaction is by far a stronger predicting factor for student achievement and behavior than student-teacher contact (Patrikakou \& Weissberg, 1999). Relationships are equally critical for students' academic achievement, especially in the area of psychological attachment and identification with adult figures who reinforce children's desire to learn (Comer, 1984). Schools therefore are to be restructured to enhance a strong positive student attachment to school.

Research studies on behavioral interventions of children with such needs as Attention Deficit Hyperactive Disorder (ADHD) and other conduct disorders tend to be more successful, when addressed within the context of home-school environments (August, Anderson, \& Bloomguist, 1992; Webster-Stratton, 1993). Additionally, findings from scientific studies on adolescents having behavioral problems indicate that interventions done with parents and school connections begin to engage in less-high risk behaviors (Resnick et al., 1997). Longitudinal studies associated with differential parental relations enhancing achievement in terms of involvement types are also recognized (Sy, Gottfried, \& Gottfried, 2013). Besides, recent studies with ethnic groups show academic socialization to be a critical determining factor of academic achievement. For example, parents with high aspiration for their children's education at the postsecondary level enhance their competency and children become more academically engaged (Fan, William, \& Wolters, 2012).

Many other researchers also found teacher invitation to parents for involvement to predict both the frequency and the effectiveness of parental involvement activities (Balli, Demo, \& Wedman, 1998; Epstein \& van Voorhis, 2001; Simon, 2004). For example, Green, Walker, Hoover-Dempsey, and Sandler (2007), Dauber and Epstein (1993) findings showed that parents' perception of teacher invitation strongly determined school-based involvement practices. Therefore, the need to examine the practice as well as the theory underpinning contemporary parent-teacher partnerships especially in Early Childhood Education is critical for many reasons. First is the fact that parenting has changed considerably in the last decade due to societal conditions. These have induced changes regarding the structure of families (Bardy, Salmi, \& Heino, 2001; Blom, 2001; Sauli \& Kainulainen, 2001). Therefore, balancing contemporary family pressures with demands of labour continues to be challenging (Ebbeck \&Waniganayake, 2003) and more complicated because of contemporary increasing demands on children to acquire specific literacy skills from an early age (OECD, 2001).

\subsection{Statement of Problem}

Many educators and research studies agree on the value of stronger family-school partnership. This notwithstanding, operationalizing such relationships can be daunting and challenging (Bempechat, 1998; Christenson \& Sheridan, 2001; Davies, 1993). Many families, including those from less endowed socioeconomic status find means to support their children's education, but often they need guidance from teachers before interacting with the school. Similarly, educators generally, and more specifically many classroom teachers, 
appear to lack the needed information to initiate collaborative partnerships with their students families, especially at the early education stage. To ensure that their contributions are fully utilized; educators especially teachers need to find ways of developing effective and productive family-school partnerships. Many research studies have been conducted in Ghana and many other African countries on the relationship between family and school. The findings suggest that students perform better where family-school relationships are stronger than where the partnership is fragile. Conspicuously absent in many studies of the family-school relationship however is an investigation focusing on the balance of reciprocity and influence of these two principal actors, especially at Early Childhood Education. Given the fact that contemporary education expects Early Childhood Education to equip children right from the onset with emergent and specific literacy skills in numeracy, reading and writing, the need to underscore identified parameters of family-school partnership at this early level of education is crucial. This research is meant to bridge this gap in the literature.

\subsection{Research Questions}

The following questions guided this research:

$>$ What criteria do teachers and parents use to determine their differential roles in children's learning during Early Childhood Education?

$>$ How do both parents and teachers see professional development in relationship to children's learning?

$>$ How do both parents perceive their relationship relative to children's learning outcomes?

$>$ What bottlenecks do parents and teachers perceive existing in building relationships?

\subsection{Significance of the study}

The findings of this study will be significant to stakeholders in Education especially to those interested Early Childhood Education. Whereas families see schools as providers of educational foundations for their children, schools also need to accept the fact that the primary responsibility of educating children lies on families. This study is again significant because scientific studies continue to demonstrate that schools that have both high parental and community involvement are more effective. Thirdly, the outcome of this study will help both parents and schools: a) perceive each partner as having equal and valuable contributions to make in children's education while simultaneously respecting their different contributions; b) both school and families would see the need to respect student needs and their preferences; c) both actors would address possible barriers especially cultural and socio-economic; d) both would see the need to create better programs, better opportunities and learning for all students regardless of family background and e)school will understand why there is the need to give families the needed opportunities to be part of the school's decision -making.

\section{Theoretical Framework / Literature Review}

\subsection{Social Exchange Theory}

Social Exchange Theory is a general socio-psychological theory explaining the conceptual framework underpinning the exchange of both material and non-material resources between individuals, as well as groups in situations of interactions. It originates as a sociological model from three sociologists, namely: Homans (1958), Blau (1964) and Emerson (1972a, 1972b). Homans (1958) developed this view from the seminal work of Skinner's (1953) operant condition psychological theory of reinforcement. For Skinner, an individual is likely to behave in a similar way if the behavior is reinforcing. Similarly, Homans (1958) posited the notion that in social interaction, especially between two individuals, the social exchange is likely to continue when each finds the others behavior as reinforcing. It could be a simple compliment, expression of agreement or some help in performing tasks of mutual help. Two variables have been derived from this theory by Chadwick-Jones 
(1976).They are: a) the frequency of rewards or costs; and b) the value attached to the rewards. In the case of the former, it is the cost involved in the social interaction. For example, if two people decide to play a game to bring mutual benefit to both, but one consistently lose the game, this could be considered the 'cost,' for which one might decide to quit the game. In this sense, Homans (1958) relates cost to the value of the possible reward. The fundamental assumption of Homans (1958) therefore is that human behavior especially in social interaction in smaller groups becomes a recipe for understanding interpersonal relations.

Emerson's work (1972a, 1972b) saw exchange relations as the basic analysis to understand social interaction rather than the outward behavior or action. Similarly, Emerson (1972a, 1972b) just as Homans (1958) also made use of the operant conditioning psychological theory as the basic unit of hypotheses. He applied this to human social learning in individual behavior in social exchange relations. This author perceived balance, dependence and power to be dyadic. In other words, exchange relations are seen to be 'balanced', when two social actors involved in the relations become equally dependent on one another. Anything less than this presupposes an imbalance in the relations. Dependency is determined when one of the actors places value on the resources of other actor. Unequal dependencies create an imbalanced exchange. This precipitates power advantage for the less dependent actor, and this potentially creates differential dependencies (Cook, 1987).

This position of Emerson (1962) rests on two fundamental processes: a) the use of power and b) balance. In an exchange relationship, when one of the actors, for example Actor A is found to be dependent on Actor B, the latter is said to have a power advantage over Actor A. This power advantage presents an imbalanced relationship in the exchange. As times goes on this imbalance begin to gravitate towards balance. For Jacobs (1970), this change over from imbalance towards balance can come about through the following predicting factors: a) finding ways to reduce the dependency of the less powerful actor on the more powerful one; b) imbalance could be reduced by searching for an alternative source of satisfaction required by the more powerful one; c) another way to reduce power imbalance is to gain some control of the sources of control required by the more powerful actor; d) inducing the more powerful to become dependent when the less dependent develops a more attractive source of satisfaction as means to reduce the inequality in the exchange relationships.

The sociologist Blau (1964) was largely influenced by Homans (1958) and Emerson (1962). His thesis in social exchange theory is this: we can only understand social structure and all the events that occur within it, by examining individual processes between people. He also used the seminal psychological ideas of the operant conditioning theory combining it with economics to offer a theoretical framework for analyzing social relations. His submission was that those individuals kept relationships as long as self-interests were satisfied, and when the perceived benefits from the social relations outweighed the costs. In this respect, an individual will maximize profits (positive reinforcements) and minimize losses (negative reinforcement) in his/her interactions with other social actors. The relationship will last so far as both actors ensure exchanges proved over the years to be rewarding are maintained, breaking off those more costly and less rewarding.

Social exchange has to do with things that get exchanged. It is not always the case that such exchange involves commodities. Various social resources, such as: expertise, physical beauty, etc. which a person possesses and based on which one becomes valuable in social relationship are social exchange (Blau, 1964). The implication here is that socially, a certain level of reciprocal principle operates, and every individual's behavior is governed by this principle of reciprocity. It is in this context that Blau makes the assertion that 'actions that are contingent on rewarding reactions from the others and that cease when these expected reactions are not forthcoming'(Blau, 1964, p. 6) This means behaviors motivated by expected response or return fails as exchange. Blau (1964) makes distinction between 'economic exchange' and 'social exchange'. In the former, payment is immediate and once payment is made, relationship ends. In the latter on the other hand, rate for social exchange is not fixed beforehand, such that payment does not conclude the exchange, exchange is a social process built upon trusting relationship. 


\subsection{Reciprocity and Social Exchange}

An implicit assumption of the social exchange theory is the principle of reciprocity. Gouldner (1960) proposed that reciprocity constitutes a global dimension of the social exchange process underscored by two fundamental elements: a) people are bound to assist those who have helped them; b) people are not expected to injure those who have helped them before. Gouldner (1960) is implying in these two core elements of reciprocity that society sees reciprocity as an obligation which it (society) has found ways to internalize in its socialization process. Thus, there is a social expectation that when a value is received, the benefit of the dividends goes back to the individual from whom the value was received.

Reciprocity as social exchange process has some conditions attached. The first condition is that it is contingent on the perceived value of the benefit (whether given or perceived). Blau (1964) extended this concept of reciprocity along two principles and Turner (1986) described these two principles as follows: a) the more people exchange relations with each other, the more likely will be the reciprocity obliging each other to ensure subsequent exchanges among themselves; b) the more reciprocal obligations are disrespected, the more deprived parties become disposed to sanctions against those violating the governing norms of the reciprocal relationships (cf. Turner, 1986, p. 264).

Concept of interdependence - The concept of reciprocity is related to interdependence. Interdependence as used here means interrelationships. Life by nature is interdependent. People who appear to be too independent may be good individuals, but can hardly be team players or good leaders (Covey, 1989). Achieving the highest independence without interdependence is a mismatch. Condeluci (1991) also perceived interdependence between peoples as the underlying factor for enhancing relationships. This is because interdependence promotes relationships. Relationships foster acceptance and mutual respect among peoples leading to empowerment for all. He made the conclusion that the fundamental problem in interdependence is more attitudinal rather than peoples: it is not peoples who are problem but rather the myopic perception of others.

Applying this to family-school partnership, it could be argued that barriers especially attitudinal barriers could exit between the two social actors- family and school. However, the issue is not the two social actors being the problem, but rather it is the seeming limited support by the educational system that precipitates the divide between family and school. Therefore, a paradigmatic shift focused more on interdependence would enhance the empowerment of the two social actors of children's early education- family and school.

\subsection{Family-school partnership in Early Childhood Education}

Epstein's (2001) Theory of Overlapping Spheres - Interdependence and reciprocity between parents and teachers are critically important in education and children's development. According to Epstein (2001), three interacting spheres: a) family; b) school, and c) the community are pivotal to the child's growth, development and education. When the three spheres collaborate, the benefits can be significant (Epstein, 1996, 2010). Similarly, when there is collaboration between parents and teachers, an enabling environment learning could be high and reduce risk of negative outcome (Bradley \& Caldwell, 1979).

Home environment and early literacy skills achievement in early childhood - Findings of empirical studies continue to provide evidence of the correlation between a conducive home environment and early literacy skills achievement (Waanders et al., 2007). This is corroborated by the findings of Wen, Bulotsky Shearer, Hahs-Vaugn, and Korfmacher (2012) showing the impact of home-based parental involvement confirmed also by Fantuzzo et al (2013). Children culturally disadvantaged from less endowed socioeconomic status, have been found to be enriched more from home-based parental involvement (Burchinal, McCartney, Steinberg, Crosnoe, Friendman, McLoyd, \& Pianta, 2011). Another kind of parental involvement is school-based in which parents volunteer and attend parent-teacher conferences (Hilado et al., 2011). Thus effective communication between parents and teachers constitutes a critical component in the education of the child (Emmen et al., 2013). 
Obstructions to parent involvement - The leading obstruction to parental involvement in their children's education are found to be the level of education of most parents. This is especially so with the mother. Many research reports suggest that parents with higher educational attainment, compared to those with little or no education are more confident and have much higher levels of competency when working on academic skills with their children in the homes (Fantuzzo, Tighe, \& Childs, 2000; Hill \& Taylor, 2004; Magnuson, Sexton, Davis-Kean, \& Huston, 2009).

Children's achievement gap - Children's educational achievement assessed in the context of ethnicity, race and socioeconomic status, most of the times show some disparities (Cameron, Grimm, Steele, Castro-Schilo, \& Grissmer, 2015). Such disparities are termed 'achievement gap'. Since early childhood is a developmental period of the human life span, during which learning occurs so rapidly, children lacking opportunity for rapid learning at this early stage, due to deprived family background and socioeconomic status, are likely to fall behind their peers. This gap can occur, even before they enter school, and the gap could be widened by early school experiences when they cannot catch up with their peers (Burchinal et al., 2011). Children's long term academic success is therefore directly related to a wide range of contextual factors (Burchinal et al., 2011; Dotterer, Iruka, \& Pungello, 2012; McCoach et al., 2010; Mollburn, Lawrence, James-Hawkins, \& Fomby, 2014). Research findings show that many children from less endowed socioeconomic status have a tendency to develop vocabulary skills slower than those from higher socioeconomic status (Anderson et al, 2015; Noel et al, 2008). Poverty limits parental resources and sensitivity to effective engagement in their children's education, heightens stress and impact negatively on physical, socioemotional as well as cognitive development (Dawson-McClure, Calzada, Huang, Kamboukos, Rhule, Kolawole, Petkova, \& Brotman, 2015; Dotterer et al., 2012; Mollburn et al., 2014). Based on the above literature, when social exchange and reciprocity are valued between social actors, outcome is hypothesized to be positive.

\subsection{Present Study}

Stronger family-school interaction based on reciprocal social exchange is perceived to be a strong predicting factor for student achievement and behavior. This notwithstanding, conspicuously absent in many research studies is an investigation focusing on the balance of reciprocity and influence of the two principal actors of family and school, especially at early childhood education in many geopolitical areas of Africa and Ghana. This is especially so, when contemporary education globally expects Early Childhood Education to equip children, even before they enter school with enhanced literacy skills. Similarly, increased economic pressures on parents complicating child rearing practices make it imperative to investigate family-school partnership parameters from other geopolitical areas at the level of Early Childhood Education. Based on this, this present study investigates family-school interactions from the following perspectives: a) the criteria teachers and parents use to determine their differential roles in children's learning during Early Childhood Education; b) How both parents and teachers see professional development in relationship to children's learning at the Early Childhood Education ; c) How both actors (parents and teachers) perceive their relationship relative to children's learning outcomes and d) What bottlenecks parents and teachers perceive existing in building such relationships?

\section{Methodology}

\subsection{Sample}

This study used a stratified random purposive sampling size of one hundred and twenty (120) respondents' from the following categories: a) forty (40) parents; b) forty (40) teachers and c) forty heads of nursery schools. They were sampled from three (3) communities in the middle belt of Ghana from the two administrative regions of Ashanti and Brong Ahafo: urban, semi-urban and rural areas in four public nursery schools. Forty participants $(n=40)$ constituting $(33 \%)$ were drawn from each of the three areas. Thirty-three percent of parents $(n=40)$, thirty-three percent of teachers $(n=40)$ and thirty-three percent of heads of nursery schools $(n=40)$ from each of 
Balance of reciprocity and influence in family-school interactions in early childhood education

the three areas took part in this survey from the three selected areas in each of the two regions. In terms of age, parents were between 24 and 48 years, with an average age of 33.85. Thirty (30) parents, constituting 75\%, reported being married and staying together with partners, while the remaining $25 \%$ were single parents. In all, $87.5 \%(n=35)$ of the participating parents were Ghanaians, while the rest were other nationals such as Nigerians, Togolese, Lebanese and few Caucasians. The children (whose parents participated in this survey) were between the ages of 3 years and 6 years old, with the average age of 4 years 6 months and an average length of one and half years of enrolment in the Early Childhood Education. All the children of these participating parents were normal developing children with no diagnosed disability.

Teachers who participated in this survey were between 24 and 35 years of age, with an average age of 28.85. Majority of them ( $n=36)$, constituting $90 \%$ were females, while the remaining four (4) (10\%) were males. Twenty five percent $(25 \%)$ of them had some professional training in Early Childhood Education, another $20 \%$ possessed the Diploma in Basic Education and the remaining 55\% had no professional training in education. Eighty percent (80\%), constituting 32 out of the 40 teachers had been teaching at the nursery/kindergarten for over fifteen (15) years, with $75 \%(n=30)$ reporting being married with children and staying with partners. Heads of these selected nurseries/kindergarten $(n=40)$ were between 40 and 55 years of age. The average age was 45.86 . Ninety percent $(n=36)$ were professional teachers with qualification in Education at the basic level. Almost all heads of these selected nurseries/kindergarten (98\%), constituting 39.2\% had been involved with Early Childhood education for more than 15 years. All were females.

\section{Table 1}

Profile of participants demographic characteristics

\begin{tabular}{|c|c|c|c|c|c|c|}
\hline Participants & $n$ & $\%$ & Gender & Educational level & Community & SES \\
\hline \multirow{3}{*}{ Parents } & \multirow{3}{*}{40} & \multirow{3}{*}{$33 \%$} & \multirow{3}{*}{$M=20 ; F=20$} & Basic school & Urban & Middle Class \\
\hline & & & & Secondary & Semi-urban & Farmer \\
\hline & & & & University/Tertiary & Rural & Hawker \\
\hline \multirow{3}{*}{ Teachers } & \multirow{3}{*}{40} & \multirow{3}{*}{$33 \%$} & \multirow{3}{*}{$M=5 ; F=35$} & Basic school & Urban & Middle Class \\
\hline & & & & Secondary & Semi-urban & Working \\
\hline & & & & University/Tertiary & Rural & Class \\
\hline \multirow{3}{*}{ Heads } & \multirow{3}{*}{40} & \multirow{3}{*}{$33 \%$} & \multirow{3}{*}{$\mathrm{M}=0 ; \mathrm{F}=40$} & Basic school & Semi-urban & Middle Class \\
\hline & & & & Secondary & Rural & Working \\
\hline & & & & University/Tertiary & University/Tertiary & Class \\
\hline
\end{tabular}

\subsection{Design and Materials}

Six kindergartens were purposively sampled from these three urban, semi-urban and rural areas. All the children were identified as Ghanaians who had English as a second language. For forty percent (40\%) of these children, English was not the primary language spoken at home. Parents signed and approved permission slips for their children to participate in a short in-school battery of cognitive test.

\subsection{Procedure and Measures}

Family Involvement Questionnaire - An adapted version of The Family Involvement Questionnaire (FIQ) originally designed by Manz Fantuzzo and Power (2004) was used to gather data. The FIQ is a 40-item measuring scale designed to gauge the level of parental engagement in their wards academic work. A caregiver who was either the biological parent or a cousin etc. completed the Questionnaire. Using a four-point Likert scale, parent or parent substitute respondents were asked to respond to the item frequency of occurrence as when it occurred in their families. The frequency was rated as follows: Rarely, Sometimes, Often, or Always. Three distinct factors were assessed: Home-Based Involvement, Home-School Communication, and School-Based Involvement. Using these factors, the researchers divided items in to the following categories: a) Home-Based Activities had nine (9) items that respondents answered; b) Home-School Communication; nine (9) items and c) School-Based Activities six (6) items. In total twenty-five (25) items were identified across the three factors. 
Ntim, S., \& Opoku-Manu, M.

Each item was marked over a grade point of four (4) making, one hundred (100)

Teacher Involvement Questionnaire - The second measuring instrument used in addition to the above was self-structured questionnaire based on an adapted version of the High School and Family Partnership Surveys of Teachers, Parents and Students originally designed from the Centre on Families Communities Schools and Children's Learning at the John's Hopkins University. This was used because it measured directly teachers' attitudes towards parents and parental involvement in schools. This instrument also examined four (4) factors, categorized as follows: a) Teachers Professional Judgment on Parental Involvement. This category examined seven (7) questions; b) Teachers Perception of Specific Ways of Involving Families, three (3) questioned were asked under this category; c) Teacher Activity to Assist Students, one (1) question; d) Teacher Perception of School-wide Support for Parents, four (4) questions were examined. For example, under the first category of Teachers Professional Judgment on Parental Involvement the following were the sub-questions: i) parental involvement is important for early childhood education; ii) this kindergarten is famous for trying new things to improve the school; iii) kindergarten needs to have strong parent organization; iv) parent involvement is critical to deepen teachers effectiveness; v) it is critical for parents to be involved in their children's early education; vi)involving families is the responsibility of teachers; vii)most of parents of kindergarten children do not know how to communicate with children about school In both measures, all the responses were coded on a 5-point Likert scale in means and standard deviations Each was marked over five (5) making thirty five marks (35). Second category was scored over 15 , third, over 50 and the last over 20 totaling one hundred (100). All scores were converted into means and standard deviations.

\section{Results}

\section{Table 2}

Interrelations between domains of criteria used by parents and teachers to determine differential roles

\begin{tabular}{|c|c|c|c|c|c|c|}
\hline \multirow[b]{2}{*}{ Domain } & \multicolumn{2}{|c|}{$\begin{array}{c}\text { Home-Based } \\
\text { Involvement } \\
n\end{array}$} & \multicolumn{2}{|c|}{$\begin{array}{c}\text { Home-School } \\
\text { Communication } \\
n\end{array}$} & \multicolumn{2}{|c|}{$\begin{array}{c}\text { School-Based } \\
\text { Involvement } \\
n\end{array}$} \\
\hline & Parent & Teacher & Parent & Teacher & Parent & Teacher \\
\hline Home-Based Involvement & 40 & 80 & 40 & 80 & 40 & 80 \\
\hline Home-School Communication & 40 & 80 & $.52 * * *$ & $.83 * * *$ & & \\
\hline School-Based Involvement & 38 & 78 & $.47 * * *$ & $.68 * * *$ & $.32 * * *$ & $.48 * * *$ \\
\hline
\end{tabular}

Note. ${ }^{* *} p<.01 * * * p<.001$

\section{Table 3}

Comparison of parents and teachers perception of professional development in children's learning

\begin{tabular}{|c|c|c|c|}
\hline & & $M D$ & $p$-Value \\
\hline Parents of children of urban centers & Teachers of children of urban centers & 6.08 & .000 \\
\hline $\begin{array}{l}\text { Parents of Higher education from urban } \\
\text { centers }\end{array}$ & $\begin{array}{l}\text { Teachers of children from rural } \\
\text { background }\end{array}$ & 8.87 & .000 \\
\hline Parents of children of semi-urban background & Teachers of semi-urban & 2.87 & .000 \\
\hline
\end{tabular}

\section{Table 4}

Comparison of parents and teachers perception of their relationship relative to children's learning outcomes

\begin{tabular}{llcc}
\hline & & $M D$ & $p$-Value \\
\hline Parents of urban background & Teachers of semi-urban background & 7.14 & .000 \\
Parents of urban background & Teachers of rural background & 10.54 & .000 \\
Parents of semi-urban background & Teachers of rural background & 6.38 & .000 \\
\hline
\end{tabular}


Balance of reciprocity and influence in family-school interactions in early childhood education

Table 5

Perceived bottlenecks of parents and teachers in building relationships

\begin{tabular}{lccc}
\hline \multicolumn{1}{c}{ Respondents } & $n$ & Mean & $S D$ \\
\hline Teachers of urban background & 25 & 95 & 0.002 \\
Parents of urban background & 15 & 96 & 0.013 \\
Teachers of semi-urban background & 25 & 94 & 0.021 \\
Parents of semi-urban background & 15 & 93 & 0.013 \\
Teachers of rural background & 30 & 90 & 0.002 \\
Parents of rural background & 10 & 98 & 0.013 \\
\hline
\end{tabular}

\section{Discussion}

A number of key differences emerged from the report. The results in Table 2 presents the ratings of parent and teacher regarding their perceptions on the interrelations between three main domains of criteria used to determine differential roles in early childhood education. Pearson chi-squared tests were used to test the normality of data. Results indicated domains were non-normal and hence non-parametric Spearman's rho tests were used in determining the correlation in the reports between parents and teachers. Besides examining teacher and parent differences across the three main domains, the tests were also utilized to examine influence of geographical location (urban, semi-urban and rural) as well as the educational attainment and experience of the respondents. As indicated in Table 2, there are positive correlations across the three domains as well as significant divergences in perceptions. For example on home-school communication $(r=.52 ; p<.001 ; r=.83 ; p<.001)$ and school-based involvement $(r=.47 ; p<.001 ; r=.68 ; p<.001)$ for parents and teachers respectively. Table 3 compares the parents and teachers perception regarding teachers' professional development for children's early learning. The results suggest that parental academic achievement as well as teachers' environment and their experience have predicting effects on the balance of reciprocity between parents and teachers. The same applies to Table 4 on children's learning outcome. On the perceived bottlenecks on building this balance of reciprocity, the differences were not significant suggesting that both groups of respondents had more or less the same perception of bottlenecks mitigating against teacher-parent partnership at Early Education.

\subsection{Parental attitudes and educational background}

One of the key findings of this report is that with respect to the criteria used by both parents and teachers to determine their differential roles in Early Childhood Education along the three inter-related domains of home-based involvement, home-school communication and school-based involvement, much of what parents did was conditioned by who they were. This is because whether or not parents feel obliged to be involved was critically shaped by their attitudes which in turn were influenced by their background especially educational attainment. As indicated in the study, there were significant differences in the responses between urban parents vis-a-vis rural parents. Whereas urban parents were more likely to be engaged in all the key domains, rural and less educated parents were not. This corroborates the study of Levitt and Dubner (2005) that much of what parents do is connected to who they are in terms of attitude and education. From the perspective of economics of education especially parental involvement as an intergenerational cultural transmission mechanism, this study also corroborated the study of Patacchini and Zenou (2007) with respect to parental social class. Social class is not unrelated to parental identity or self-image which is sociologically perceived as function of connection between the ideals for the chosen social entity vis-à-vis parental actual behavior as well as characteristics. This was also evident in this study. Urban middle class parents felt more at ease to be involved with the school than their rural counterparts.

This is also in line with other studies suggesting that parental high level of education and for that matter of higher social class has more heightened preference for cared-for children. This explains why children from less endowed socioeconomic status, compared to their peers have a tendency to develop vocabulary skills slower than those from higher socioeconomic status (Anderson et al., 2015; Noel et al., 2008. Deprivation, most often 
limits parental resources and sensitivity to effective engagement in their children's education. It also heightens stress and impact negatively on physical, socio-emotional as well as cognitive development (Dawson-McClure, Calzada, Huang, Kamboukos, Rhule, Kolawole, Petkova, \& Brotman, 2015; Dotterer et al., 2012; Mollburn et al., 2014). Additionally, this empirical finding also support the Hoover-Dempsey and Sandler (1995) psychological model that three constructs basically determine parental involvement decisions: a) their belief of what parents are to do regarding their children's education; b) parental sense of efficacy to help their children to succeed and c) whether or not parents perceive that the school and the child expect them to be involved.

\subsection{Parents and teachers perception of professional development in relationship to children's learning}

On teachers' perspectives regarding their professional judgment of parental involvement, seventy (70) respondents out of the forty (teachers) and forty headmasters, constituting $87.5 \%$ strongly agreed that parents needed to be involved in early childhood education. However, responding to similar question whether new ideas were needed from parents to improve schools, response varied: while thirty (30) that is $37.5 \%$ strongly agreed, twenty (20) (25\%) agreed, fifteen (15) did not agree and the other fifteen (15) were undecided. Similarly, a question that related parental involvement to teacher effectiveness received low ratings especially from the teachers. Rather, seventy (70) respondents $(87.5 \%)$ out of the teachers and school head teachers responded with high ratings that parental involvement on the other hand enhances student effectiveness and not teacher effectiveness. This finding underscores the fact that many teachers still fail to appreciate the differential parental roles that enhance teacher effectiveness at early education and does not support the findings of Sy et al. (2013). For example, whereas in the studies conducted by these authors, parents play double involvement to enhance early literacy skills: a) academic instruction and b) academic socialization. In the former, parents help to develop specific intellectual skills such as reading and in the latter they help to create stimulating learning environment through the inculcation of beliefs and expectations and by so doing making the teachers work in school more effective.

This finding suggest the opposite indicating that for teacher respondents in this survey, parents' involvement only helps students' effectiveness' and not teacher effectiveness. As regards parental perception as indicated above, it was conditioned by the level of the education and social class of parents. Less educated rural parents in this study were less likely to feel obliged to offer professional development relating to their children's learning, confirming Green et al. (2007) that the way parents perceived specific teacher/school invitation influenced their school-based involvement. Thus, unless the invitation was thrown to such parents by teachers/school their participation would be poor.

\subsection{Parents and teachers perception of their relationship relative to children's learning outcomes}

The divergences in perception between parents and teachers as indicated in Table 4 appears be greater between parents of urban background and teachers of rural background with a mean difference of 10.53 with $p$-Value of .000 Urban parents were of the view that their partnership with the school/teacher was more critical especially at this early education even in their children's learning outcome. Rural teachers with less experience and less qualification were of the view that inasmuch as parental involvement of learning outcomes was concerned, it was more the responsibility of the teacher than parents. If anything, parents could be helped how to assist their children with school work in the homes.

This finding support the submission of recent empirical studies on student achievement gap that children from a more supportive, sensitive as well as interactive parents who are academically competent with school staff regarding their children's learning outcome are predicted to do better because parents feel equally competent in their children's learning outcome (Dotterer, Iruka, \& Pungello, 2012; McCoach et al., 2010 ) Thus urban and educated parents parental tend to have heightened sensitivity to children's early childhood education which is critical in the child's early development of literacy skill such language development. 


\subsection{Perceived bottlenecks of parents and teachers existing in building relationships}

Both respondents perceived three critical bottlenecks obstructing parents and teachers in building effective relationships: a) communication from the school to the homes; b) lack of effective survey of parents each year on ideas to be developed; c) parent-teacher conferences. The mean scores and standard deviations are not significantly different except with the rather strange exception of the scores between the rural teachers and rural parents. Rural parents scored higher meaning they perceived more obstructions as existing in building this relationship. For example, with respect to communication from the school to the home, whether or not it needed to be developed or improved, the ranking based on the Likert scale showed that $93.75 \%$ of teachers and head teachers (constituting 75 out of the 80) were of the view that it needed to be improved, implying that it existed, but needed improvement. Majority of parents, especially from the rural background concurred with the teachers.

Regarding the need for survey of parents each year on their views about the school, all respondents across the three backgrounds (urban, semi-urban and rural) admitted this as a serious lacuna that needed to be developed, meaning in all the preschools surveyed in this report, this was not existent. Parent-teacher conferences were deemed to be crucial. However an interesting finding was that most of the teachers did not even have the contact numbers of the parents of the children and vice versa. Additionally, in as much as teachers perceived this to be important, they felt that it was not the prerogative of parents to tell them how to teach their children. This finding is significant since it appears to reinforce the sociological principle of 'balance' when two social actors are involved in exchange of dyadic relations. There is mutual dependency when both actors place value on the resources of the other. Unequal dependencies as seem to suggest by this response precipitates power advantage especially for the less dependent (Emerson, 1962; Cook, 1987). This can undermine the mutuality needed from both actors.

\section{Conclusion}

Family-school partnership at the level of Early Education with both families and schools working to enhance effective learning cannot be underestimated. This is especially so in this era and age when contemporary education expects Early Childhood Education to equip children with specific literacy skills in numeracy and reading within the context of increased economic pressures on parents which complicate child rearing practices. The need to construct such partnership, identify the differential roles of the two principal actors at this initial level of education, and how to initiate and sustain these connections were the focus of this paper. The key findings were that parents and teachers showed differences as well as similarities in their over-all assessment of the perception of their respective roles. Professional judgment of teachers on parental involvement indicated that teachers at the early education level expected parents to be more involved in the homes and in the schools, but with the appropriate level of parental involvement in the latter. Whether or not parents felt obliged to be involved was critically shaped by their attitudes which in turn were influenced by their background, especially educational attainment. There were significant differences in the responses between urban parents vis-a-vis rural parents. Whereas some parental responses suggested unequal dependencies and power advantage in all the key domains in rural and less educated parents, it was less so with urban educated parents.

Notes: The corresponding author did all the literature review, designed the data collection instruments and the statistical analysis, while the second author conducted all the field work in the selected preschools.

Acknowledgement: The authors thank all respondents who voluntarily participated in this survey.

Competing Interest: The authors have no competing interest in this research and declare that no funds were received from any source to conduct this study. 


\section{References}

Abdulkadir, M. D., Ali, A. M., \& Raqia, A. M. (2018). The role of parental involvement in student academic achievement: Empirical study from secondary schools in Mogadishu-Somalia. International Research Journal of Human Resource and Social Science, 5(7), 1-24.

Anderson, J. A., Howland, A. A., \& McCoach, B. D. (2015). Parental characteristics and resiliency in identification rates for special education. Preventing School Failure, 59(2), 63-72. https://doi.org/10.1080/1045988X.2013.837811

August, G. J., Anderson, D., \& Bloomquist, M. L. (1992). Competence enhancement training for children: An integrated child, parent, and school approach. In S. L. Christenson \& J. C. Conoley (Eds.), Home-school collaboration: Enhancing children's academic and social competence (pp. 175-192). Silver Spring, MD: National Association of School Psychologists.

Balli, S. J., Demo, D. H., \& Wedman, J. F. (1998). Family involvement with children's homework: An intervention in the middle grades. Family Relations, 47, 149-157. https://doi.org/10.2307/585619

Bardy, M., Salmi, M., \& Heino, T. (2001). Mikä lapsiamme uhkaa? Suuntaviivoja 2000-luvun lapsipoliittiseen keskusteluun [What is threatening our children? Guidelines for child political discourses in 2000]. Reports of Stakes no. 263. Helsinki: Stakes.

Bempechat, J. (1998). Against the odds: How “at-risk” students EXCEED expectations. San Francisco: Jossey-Bass.

Blau, P. M. (1964).Exchange and power in social life. New York: Wiley and Sons.

Blom, R. (2001). Yhteiskunnan rakennemuutos ja perheiden elinehdot [Structural change in the society and living conditions in the families]. In I. Järventie \& H. Sauli (Eds.), Eriarvoinen lapsuus [Unequal childhood] (pp. 171-192). Helsinki: WSOY.

Bradley, R. H., \& Caldwell, B. H. (1979). Home observation for measurement of the environment: A revision of the preschool scale. American Journal of Mental Deficiency, 84(3), 235-244.

Burchinal, M., McCartney, K., Steinberg, L., Crosnoe, R., Friedman, S. L.,McLoyd, V., Pianta, R., \& NICHD Early Child Care Research Network. (2011). Examining the black-white achievement gap among low-income children using the NICHD study of early child care and youth development. Child Development, 82(5), 1404-1420. https://doi.org/10.1111/j.1467-8624.2011.01620.x

Cameron, C. E., Grimm, K. J., Steele, J. S., Castro-Schilo, L., \& Grissmer, D. W. (2015). Nonlinear gompertz curve models of achievement gaps in mathematics and reading. Journal of Educational Psychology, 107(3), 789-804. https://doi.org/10.1037/edu0000009

Chadwick-Jones, J. K. (1976). Social exchange theory: Its structure and influence in social psychology. New York: Academic Press.

Christenson, S. L., \& Sheridan, S. M. (2001). School and families: Creating essential connections for learning. New York, NY: Guilford Press.

Comer, J. P. (1984). Home-school relationships as they affect the academic success of children. Education and Urban Society, 16(3), 323-337. https://doi.org/10.1177/0013124584016003006

Condeluci, A. (1991). Interdependence: The route to community. Florida: Paul M. Deutsch Press.

Cook, K. S. (1987). Emerson's contributions to social exchange theory. In K. S. Cook (Ed.), Social exchange theory (pp. 209-222).Newbury Park: Sage.

Covey, S. R. (1989). The 7 habits of highly effective people. New York: Simon and Schuster.

Dauber, S. L., \& Epstein, J. L. (1993). Parents' attitudes and practices of involvement in inner-city elementary and middle schools. In N. F. Chavkin (Ed.), Families and schools in a pluralistic society (pp. 53-71). Albany: State University of New York Press.

Davies, D. (1993). Benefits and barriers to parent involvement: From Portugal to Boston to Liverpool. In N.F. Chavkin (Ed.), Families and schools in a pluralistic society (pp. 53-72). Albany: State University of New York Press.

Dawson-McClure, S., Calzada, E., Huang, K. Y., Kamboukos, D., Rhule, D.Kolawole, B., Petkova, E. \& Brotman, L. M. (2015). A population-level approach to promoting healthy child development and 
Balance of reciprocity and influence in family-school interactions in early childhood education

school success in low-income, urban neighborhoods: impact on parenting and child conduct problems. Society for Prevention Research, 16, 279-290. https://doi.org/10.1007/s11121-014-0473-3

Dotterer, A. M., Iruka, I. U., \& Pungello, E. (2012). Parenting, race, and socioeconomic status: links to school readiness. Family Relations, 61, 657-670. https://doi.org/10.1111/j.1741-3729.2012.00716.x

Ebbeck, M., \& Waniganayake, M. (2003). Early childhood professionals: Leading today and tomorrow. Sydney: MacLennan Petty.

Emerson, R. M. (1962). Power dependence relations. American Sociological Review, 27, 31-41. https://doi.org/10.2307/2089716

Emerson, R. M. (1972a). Exchange theory part I: A psychological basis for social exchange. In J. Berger, M. Zelditch, Jr., \& B. Anderson (Eds.), Sociological theories in progress (pp. 38-57). Boston: Houghton Mifflin.

Emerson, R. M. (1972b). Exchange theory Part II: Exchange rules and networks. In J. Berger, M. Zelditch, Jr., \& B. Anderson (Eds.), Sociological theories in progress (pp. 58-87). Boston: Houghton Mifflin.

Emmen, R. A. G., Malda, M., Mesman, J., van IJzendoorn, M. H., Prevoo, M. J. L., \& Yeniad, N. (2013). Economic status and parenting in ethnic minority families: Testing a minority family stress model. Journal of Family Psychology, 27(6), 896-904. https://doi.org/10.1037/a0034693

Epstein, J. (1996). This we believe and now we must act: Improving school family- community partnerships in the middle grades. Middle School Journal, 28(2), 43-48. https://doi.org/10.1080/00940771.1996.11494440

Epstein, J. L. (2001). School, family, and community partnerships. Preparing educators and improving schools. Boulder, CO: Westview Press.

Epstein, J. L. (2010). School/family/community partnerships: Caring for the children we share. Phi Delta Kappan, 92(3), 701-712. https://doi.org/10.1177/003172171009200326

Epstein, J. L., \& Van Voorhis, F. L. (2001). More than minutes: Teachers 'roles in designing homework. Educational Psychologist, 36(3), 181-193. https://doi.org/10.1207/S15326985EP3603_4

Fan, W., Williams, C. M., \& Wolters, C. A. (2012). Parental involvement in predicting school motivation: Similar and differential effects across ethnic groups. The Journal of Educational Research, 105, 21-35. https://doi.org/10.1080/00220671.2010.515625

Fantuzzo, J., Gadsden, V., Li, F., Sproul, F., McDermott, P., Hightower, D., \& Minney, A. (2013). Multiple dimensions of family engagement in early childhood education: evidence for a short form of the family involvement questionnaire. Early Childhood Research Quarterly, 28, 734-742. https://doi.org/10.1016/j.ecresq.2013.07.001

Fantuzzo, J., Tighe, E., \& Childs, S. (2000). Family involvement questionnaire: A multivariate assessment of family participation in early childhood education. Journal of Educational Psychology, 92(2), 367-376. https://doi.org/10.1037/0022-0663.92.2.367

Gouldner, A. W. (1960). The norm of reciprocity: A preliminary statement. American Sociological Review, 25(2), 161-178. https://doi.org/10.2307/2092623

Green, C. L., Walker, J. M. T., Hoover-Dempsey, K. V., \& Sandler, H. M. (2007). Parents' motivations for involvement in children's education: An empirical test of a theoretical model of parental involvement. Journal of Educational Psychology, 99, 532-544. https://doi.org/10.1037/0022-0663.99.3.532

Hilado, A., Kallemeyn, L., Leow, C., Lundy, M., \& Israel, M. (2011). Supporting child welfare and parent involvement in preschool programs. Early Childhood Education Journal, 39, 343-353. https://doi.org/10.1007/s10643-011-0471-z

Hill, N. E., \& Taylor, L. C. (2010). Parental school involvement and children's academic achievement. Current Directions in Psychological Science, 13(4), 161-164. https://doi.org/10.1111/j.0963-7214.2004.00298.x

Homans, G. C. (1958). Social behavior as exchange. American Journal of Sociology, 63, 597-606. https://doi.org/10.1086/222355

Hoover-Dempsey, K., \& Sandler, H. (1995). Parental involvement in children's education: Why does it make difference? Teachers College Record, 97, 310-331.

Jacobs, T. O. (1970). Leadership and exchange in formal organizations. Alexandria, VA: Human Resources 
Ntim, S., \& Opoku-Manu, M.

Research Organization. https://doi.org/10.21236/AD0725584

Levitt, S. D., \& Dubner, S. J. (2005). Freakonomics: A rogue economist explores the hidden side of everything. New York: William Morrow.

Lewis, A. C., \& Henderson, A. T. (1997). Urgent message: Families crucial to school reform. Washington, DC: Center for Law and Education.

Magnuson, K. A., Sexton, H. R., Davis-Kean, P. E., \& Huston, A. C. (2009). Increases in maternal education and young children's language skills. Merrill-Palmer Quarterly, 55, 319-350. https://doi.org/10.1353/mpq.0.0024

Manz, P. H., Fantuzzo, J. W., \& Power, T. J. (2004). Multidimensional assessment of family involvement among urban elementary students. Journal of School Psychology, 42, 461-475. https://doi.org/10.1016/j.jsp.2004.08.002

McCoach, D. B., Goldstein, J., Behuniak, P., Reis, S. M., Black, A. C., Sullivan, E. E., \& Rambo, K. (2010). Examining the unexpected: Outlier analyses of factors affecting student achievement. Journal of Advanced Academics, 21(3), 426-468. https://doi.org/10.1177/1932202X1002100304

Mollburn, S., Lawrence, E., James-Hawkins, L., \& Fomby, P. (2014). When do socioeconomic resources matter most in early childhood? Advances in Life Course Research, 20, 56-69. https://doi.org/10.1016/j.alcr.2014.03.001

Noel, M., Peterson, C., \& Jesso, B. (2008). The relationship of parenting stress and child temperament to language development among economically disadvantaged preschoolers. Journal of Child Language, 35(4), 823-843. https://doi.org/10.1017/S0305000908008805

OECD. (2001). Starting strong: Early childhood education and care. Paris: OECD. https://doi.org/10.1787/9789264192829-en

Patacchini, E., \& Zenou, Y. (2007). Intergenerational education transmission: Neighborhood quality and/or parents' involvement? IZA DP No. 2608.

Patrikakou, E. N., \& Weissberg, R. P. (1999). The seven P's of school-family partnerships. Education Week, 18(21), 34- 36.

Resnick, M. D., Bearman, P. S., Blum, R. W., Bauman, K. E., Harris, K. M., Jones, J., Tabor, J., Beuhring, T., Sieving, R. E., Shew, M., Ireland, M., Bearinger, L. H., \& Udry, J. (1997). Protecting adolescents from harm: Findings from the National Longitudinal Study on adolescent health. The Journal of the American Medical Association, 278(10), 823-832. https://doi.org/10.1001/jama.1997.03550100049038

Sauli, H., \& S. Kainulainen. (2001). Yhteiskunnan muutos ja lapsiperheet [Amendment in society and families with children]. In M. Törrönen (Ed.), Lapsuuden hyvinvointi. Yhteiskuntapoliittinenpuheenvuoro [Wellbeing in childhood. A social-political statement] (pp. 42-57). Helsinki: Pelastakaa lapsetry.

Simon, B. S. (2004). High school outreach and family involvement. Social Psychology of Education, 7, 185-209. https://doi.org/10.1023/B:SPOE.0000018559.47658.67

Skinner, B. F. (1953). Science and human behavior. New York: Macmillan.

Sy, S. R., Gottfried, A. W., \& Gottfried, A. E. (2013). A transactional model of parental involvement in children's achievement in early childhood and adolescence, Parenting, Science and Practice, 2(13) 133-152. https://doi.org/10.1080/15295192.2012.709155

Turner, J. H. (1986). The structure of sociological theory. Chicago: Dorse.

Waanders, C., Mendez, J. L., \& Downer, J. T. (2007). Parent characteristics, economic stress and neighborhood context as predictors of parent involvement in preschool children's education. Journal of School Psychology, 45, 619-636. https://doi.org/10.1016/j.jsp.2007.07.003

Webster-Stratton, C. (1993). Strategies for helping school-age children with oppositional defiant and conduct disorders: The importance of home-school partnerships. School Psychology Review, 22, 437-457.

Wen, X., Bulotsky-Shearer, R. J., Hahs-Vaughn, D. L., \& Korfmacher, J. (2012). Head start program quality: Examination of classroom quality and parent involvement in predicting children's vocabulary, literacy, and mathematics achievement trajectories. Early Childhood Research Quarterly, 27, 640-653. https://doi.org/10.1016/j.ecresq.2012.01.004 